Stanislaw Plaza

(Kraków)

\title{
Rozwój staropolskiego prawa sq̨dowego na tle tendencji europejskich
}

\section{Entwicklung des altpolnischen Gerichtsrechts im Vergleich zu den europäischen Tendenzen}

\author{
1. Źródła prawa. 2. Prawo prywatne. 3. Prawo karne. 4. Procedura sądowa. \\ 1. Quellen des Rechts. 2. Privatrecht. 3. Strafrecht. 4. Gerichtsverfahren.
}

1.1. W Polsce od połowy XII w. społeczeństwo zaczęło rozpadać się na wielkie grupy spoleczne - stany, które różniły się między sobą pozycją gospodarczo-społeczną oraz odrębnym położeniem prawnym (bardziej lub mniej uprzywilejowanym). To odrębne stanowisko prawne wyrażało się przede wszystkim w uzyskiwaniu własnego sądownictwa i właśnie osobnego prawa. Proces ten, który objął także wiele krajów europejskich, zakończył się w XIV w., kiedy to w pełni wyksztalciły się odrębne prawa stanowe, w zasadzie inne dla każdego stanu. Rycerstwo (szlachta) miało swoje prawo (ziemskie lub lenne), mieszczaństwo rządziło się swoim prawem, duchowieństwo podlegało prawu kanonicznemu. Chłopi wprawdzie nie wszędzie i nie zawsze stanowili odrębny stan, ale obowiązywało wobec nich $w$ wielu krajach ( $w$ tym również w Polsce) także odmienne prawo (chłopskie, wiejskie, dworskie), które jednak zawieralo wiele elementów innych systemów prawa. Ta stanowość prawa występowała powszechnie $w$ krajach europejskich ( $\mathrm{z}$ wyjątkiem Anglii) w mniej lub bardziej ostrych formach i utrzymała się aż do wielkich reform kodyfikacyjnych $z$ drugiej połowy XVIII w. ${ }^{1}$

1.2. Poza prawem kanonicznym pozostałe systemy wykazywały znaczny partykularyzm terytorialny, tworząc prawa lokalne o większym lub mniejszym zasięgu, w czym również wyrażał się brak powszechności prawa. Szczególnie

' S. Ru s socki, Monarchia i stany w Polsce późnego średniowiecza, Przegl. Hum. 1993, nr 2. 
w okresie rozbicia dzielnicowego (XII-XIII w.) powstawała w wielu krajach ogromna liczba praw lokalnych - zarówno ziemskich, miejskich, jak i wiejskich. Obejmowały swoim zasięgiem nieraz calkiem male terytoria. W Polsce partykularyzm prawa ziemskiego wywodził się z odrębności dzielnicowych. Wyróżniały się przede wszystkim trzy zasadnicze odmiany prawa ziemskiego: wielkopolska ${ }^{2}$, małopolska ${ }^{3}$ i mazowiecka ${ }^{4}$. Po inkorporacjach i uniach doszły jeszcze odrębności prawa Prus Królewskich ${ }^{5}$ i Wielkiego Księstwa Litewskiego ${ }^{6}$. Prawo miejskie i wiejskie wykazywały jeszcze dalej posunięty partykularyzm terytorialny. W prawie miejskim wyodrębnily się: prawo magdeburskie ${ }^{7}$, średzkie ${ }^{8}$ i chelmińskie?.

$\mathrm{Z}$ czasem ulegaly one dalszemu poważnemu zróżnicowaniu. Prawo wiejskie w ogóle nie tworzyło jednolitego systemu, zawierało liczne pierwiastki $\mathrm{z}$ innych systemów (przede wszystkim niemiecko-miejskiego).

${ }^{2}$ Statuty Kazimierza Wielkiego, cz. 2: Statuty Wielkopolskie, wyd. L. Lysiak, Warszawa 1982.

${ }^{3}$ Statuty Kazimierza Wielkiego (redakcja malopolska), opr. O. Balzer, Poznań 1947.

Iura Masoviae Terrestria, Pomniki dawnego prawa mazowieckiego ziemskiego, t. 1-3: 1228-1540, wyd. J. Sawicki, Warszawa 1972-1974; Sredniowieczne prawa mazowieckiego pomniki: 1377-1496, wyd. O. Balzer, Arch. Kom. Praw. PAU 1897, 5; S. R u s s ocki, Ustrój polityczny i prawo, [w:] Dzieje Mazowsza, Warszawa 1994, s. 294-326.

5 Akta Stanów Prus Królewskich, t. 1-8; 1479-1526, wyd. K. Górski, M. Biskup, I. Janusz-Biskupowa, Torún 1955-1993; M. B is k u p, I. J a n u sz-B i sk u p ow a, Odnaleziony reces zjazdu Stanów Prus Królewskich i Krzyżackich w Grudziqudzu z 23 IV 1523 r., Zap. Hist. 1996, t. 61, z. 2-3, s. 71-83; Z. Zd rójk ow sk i, Korektura pruska-jej powstanie, dzieje oraz jej rola w historii polskiej jurysdykcji i myśli prawniczej (1598-1830), CPH 1961, t. 13, z. 2, s. 109-157.

${ }^{6}$ Zob. przyp. 21.

7 Poznańska ksiega prawa magdeburskiego i miśnieńskiego, wyd. M. Maisel, Kraków 1964; Magdeburger Recht, T. 2: Rechtsmitteilungen und Rechtssprüche für Breslau, cz. 2: Die Quellen von 1453 bis zum Ende des 16. Jahrhundert, wyd. F. Ebel, Köln-Weimar-Wien 1995; Der rechte Weg: ein Rechtsbuch des 15. Jahrhunderts, T. 1-2, Köln-Weimar-Wien 2000; Studien zur Geschichte des sachsisch-magderburgischen Rechts in Deutschland und Polen, wyd. D. W. Willoweit, W. Schich, Frankfurt am Main 1980; Z. J. K op ys ski, Magdeburskoje prawo $w$ gorodach Bielarussii (Koniec XV - pierwaja polowina XVII w.), Sowwiet. Stawianowied. $1972,8, \mathrm{nr} 5$.

${ }^{8}$ Z. Zdrójk owski, Geneza prawa średzkiego i jego rola dziejowa (1223-1511), [w:] Studia $z$ dziejów Srody Staskiej, Wrocław 1990; K. K a mińsk a, Prawo średzkie jako instrument polityki osadniczej i gospodarczej w Polsce od XIII do poczq̨tku XVI w., [w:] Historia integra. Ksiega pamiqutkowa ofiarowana prof. S. Salmonowiczowi, Toruń 2001, s. 147-160.

${ }^{9}$ Das Kulmer Gerichtsbuch 1330-1430. Liber memoriarum Colmensis Civitatis, wyd. C. A. Lückerath u. F. Benninghoven, Köln-Wien 1999, s. X, 394; Rewizja lidzbarska prawa chelmińskiego 1566 (1711), przekł. z łac. i niem. A. Groth, Koszalin 1997, s. 247; T. G o s, Znaczenie "Prawa starochelmińskiego" dla medycyny sqdowej, Arch. Med. Sąd. Kryminol. 1997, 47, z. 2, s. 121-127; T. M a cie je w sk i, Prawo chelmińskie w Gdańsku, Gd. St. Praw. 2000,7 , s. 361-364; K. Zi elińs k a-M e1k owa, Geneza przywileju chelmińskiego z 1233 i 1251 oraz jego znaczenie dla rozwoju osadnictwa na terenach Polski Pólnocnej w XIII $i$ XIV w., Rocz. Grudz. 2001, nr 14, s. 9-24; zob. też S. Płaza, Historia prawa w Polsce na tle porównawczym, cz. I: X-XVIII w., Kraków 1997, s. 117-118, 153. 
$Z$ czasem wpływali na nie $w$ dużym stopniu posiadacze wsi $^{10}$. Ten partykularyzm prawa utrzymal się aż do rozbiorów Polski; w Europie (poza Anglią) występował powszechnie, osiągając w niektórych krajach ogromne rozmiary (np. we Francji w XV w. było kilkaset - ok. 700 praw lokalnych) ${ }^{11}$.

1.3. Oprócz prawa kanonicznego pozostałe systemy miały przez całe stulecia w przeważającej mierze charakter prawa zwyczajowego. Było ono rozwijane przez orzecznictwo sądów, zwłaszcza wyższych, ale zmiany dokonywane tą drogą następowaly powoli; stąd prawo zwyczajowe $\mathrm{z}$ natury rzeczy miało charakter konserwatywny, a przy tym wykazywało znaczną niepewność i rodziło często wątpliwości. Tę niepewność prawa zwyczajowego pogłębiał jeszcze fakt, iż przez dlugi czas było ono prawem niepisanym, opartym tylko na ustnej tradycji. Dopiero od XIII w. podejmowano próby jego spisywania. Spisy te najpierw mialy charakter prywatny. Poza prawem wiejskim, już od średniowiecza prawo ziemskie i miejskie były $w$ Polsce wprawdzie $w$ ciągu stuleci spisywane (od XIV w.), ale te zbiory nie objęły całości; miały $w$ zasadzie charakter częściowy, partykularny i przy tym głównie prywatny, a dopiero $\mathrm{z}$ czasem urzędowy. W Polsce prawo zwyczajowe utrzymało swoje dominujące znaczenie aż do rozbiorów. Podobnie było w wielu krajach Europy, gdzie ograniczenie lub zmierzch prawa zwyczajowego przyniosły dopiero oświeceniowe kodyfikacje z drugiej polowy XVIII w. lub rewolucja we Francji; w Niemczech zaś to prawo traciło na znaczeniu wskutek recepcji prawa rzymskiego ${ }^{12}$.

1.4. Prawo stanowione od początku i stale tworzylo podstawę prawa kanonicznego. Natomiast świeckie prawo stanowione rozwijało się powoli, ale jego rola jednak wzrastała, co było zresztą ściśle związane $\mathrm{z}$ rozrastającymi się funkcją i znaczeniem aparatu państwowego. Najpierw bezpośrednia interwencja ustawodawcza obejmowała organizację samego

${ }^{10}$ Polskie ustawy wiejskie $X V$-XVIII w., wyd. S. Kutrzeba i A. Mańkowski, Kraków 1938; A. G ąs i or ow ski, Ze studiów nad szerzeniem sie tzw. prawa niemieckiego we wsiach ziemi krakowskiej $i$ sandomierskiej (do 1333 r.), Rocz. Hist. 1960, $\mathrm{nr} 26$; J. M a u szewsk i, Prawo sq̨dowe na wsi polskiej lokowanej na prawie niemieckim, [w:] Studia z dziejów państwa i prawa polskiego, [dalej: SDPiPP], t. 2, Lódź 1995; J. M. P i sk or ski, Średniowieczna kolonizacja niemiecka oraz $t z w$. prawo niemieckie w ujęciu porównawczym, [w:] Rozkwit, Warszawa 2001, s. 94-139; T. T y c, Poczqtki kolonizacji wiejskiej na prawie niemieckim $w$ Wielkopolsce (1200-1233), [w:] te nż e, Z średniowiecznych dziejów Wielkopolski, Poznań 1997, s. 5-137; L. Ty s zk i ewi cz, Ślask przed lokacja i kolonizacja na prawie niemieckim, [w:] Ksiega Jadwiżańska, Wrocław 1995; A. V e t u 1 a n i, W sprawie prawa chlopskiego w Polsce feudalnej, PiP 1956, nr 12.

11 S. Płaza, Historia prawa..., s. 102, 175.

${ }^{12}$ P. B ender, Die Rezeption des römischen Rechts im Urteil des deutschen Rechtswissenschaft, Freiburg 1955; K. M odz el e w ski, Legem ipsam vetare non possumus. Królewski kodyfikator wobec potggi zwyczaju, [w:] Historia - idee - polityka. Ksiega dedykowana prof. J. Baszkiewiczowi, Warszawa 1995, s. 26-32; W. U r u s z c z a k, Zwyczaj a ustawa w staropolskiej myśli prawniczej, [w:] $Z$ historii państwa i prawa... Prace ofiarowane prof. W. Ćwikowi, Rzeszów 1998, s. 263-279. 
państwa $w$ skarbowości i siły zbrojnej, potem przechodzila do wymiaru sprawiedliwości oraz prawa sądowego (wcześniej karnego i procesowego, później prywatnego).

W dobie monarchii stanowej (XIV-XV w.), kiedy państwo stalo się względnie scentralizowane, władza podejmowała próby unifikacji (kodyfikacji) prawa, które nadal miało przeważnie charakter zwyczajowy. Za Kazimierza Wielkiego (polowa XIV w.) prawo ziemskie (szlacheckie) zostalo zunifikowane (skodyfikowane) w dwóch statutach: wielkopolskim i małopolskim. Pierwszy zawieral głównie prawo zwyczajowe; drugi usuwał przepisy przestarzałe, a wprowadzał nowe oraz pomyślany był jako zalążek ogólnopolskiej kodyfikacji. Oba statuty obejmowały ustrój państwa i prawo sądowe, ale niewyczerpujące; najwięcej było przepisów karnych i proceduralnych ${ }^{13}$. Uzupelniał tę kodyfikację statut warcki $(1423 \mathrm{r} .)^{14}$. Wszakże w orzecznictwie sądowym była ona pomijana ${ }^{15}$.

Inny był los znakomitej czeskiej kodyfikacji (Maiestas Karolina) z tego samego czasu (połowa XIV w.), która w sposób całościowy obejmowała czeskie prawo ziemskie (publiczne i sądowe); wykazywała wpływy prawa rzymskiego oraz wiele innowacji. Szlachta sprzeciwiła się jednak jej zatwierdzeniu, gdyż wzmacniała władzę króla, ale w praktyce prawnej była powszechnie stosowana ${ }^{16}$.

Od końca XV w. główny udział w rozwijaniu prawa stanowionego w Polsce przypadł konstytucjom (ustawom) sejmowym. Wszakże żywsza działalność ustawodawcza zaznaczyła się tylko w XVI w., potem wyraźnie ona słabła, a od polowy XVII w., kiedy sejmy coraz częściej nie dochodziły do skutku, nastąpił wręcz pewien zastój w rozwoju ustawodawstwa. Ale dzialalność ustawodawcza, nawet wtedy, kiedy się rozwijała, jak w XVI w., była niewielka w zakresie prawa sądowego, a już zupełnie znikoma $w$ dziedzinie prawa prywatnego; poza tym były to zazwyczaj regulacje cząstkowe ${ }^{17}$.

${ }^{13}$ L. Korczak, Kazimierz Wielki - inicjator Statutów wiślickich, [w:] SDPiPP, t. 5, Lódź 1999, s. 45-51; J. Matu szewski, Geneza statutów Kazimierza Wielkiego, [w:] t e nże, Pisma, t. 2, Lódź 2000, s. 75-92; t e nż e, Prawo niemieckie w Statutach Kazimierza Wielkiego, [w:] SDPiPP, t. 3, Lódź 1999, s. 53-80; W. U r u s z c z a k, Argumenty retoryczne w Statutach Kazimierza Wielkiego, [w:] Dawne prawo i myśl prawnicza. Prace poświęcone pamięci W. $M$. Bartla, Kraków 1995, s. 267-282; t en że, Statuty Kazimierza Wielkiego jako źródlo prawa polskiego, [w:] SDPiPP, t. 3, Lódź 1999, s. 97-115; t e nże, Zwyczaje ziemskie w Statutach Kazimierza Wielkiego, [w:] SDPiPP, t. 4, Lódź 1999, s. 177-187.

${ }^{14}$ W. Uruszczak, Z badań nad statutem warckim z 1423 r., [w:] Parlamentaryzm [...] prace dedykowane prof. S. Plazie, Kraków 1999, s. 135-147.

${ }^{15}$ L. Ly si a k, Statuty Kazimierza Wielkiego w malopolskiej praktyce sqdowej XV w., SH 1976, 19 , z. 1 .

${ }^{16}$ Maiestas Carolina, wyd. H. Jirećek, Codex Iuris Bohemici 1870, 2, cz. 2; J. Hobzek, Maiestas Carolina a rimské pravo, Praha 1931.

17 Volumina Legum, t. 1-8, wyd. J. O h r y z k o, Petersburg 1859-1860, przedruk: Warszawa 1980, t. 9, wyd. Akad. Umiejętn., Kraków 1889, t. 10; wyd. PTPN, Poznań 1952; Volumina 
1.5. Prace unifikacyjne (kodyfikacyjne) podjęto $w$ Polsce $w$ szerokim zakresie w XVI w. Pierwszą poważniejszą próbą w omawianym okresie uporządkowania prawa obowiązującego $\mathrm{w}$ Polsce było ułożenie $\mathrm{i}$ wydanie drukiem (po łacinie) w 1506 r., z inicjatywy króla i sejmu, przez kanclerza koronnego Jana Laskiego, obszernego zbioru praw zwanego potocznie, acz niezbyt ściśle, Statutem Laskiego. Stanowił on krok w kierunku stworzenia wspólnego dla całego państwa kodeksu prawa. Składał się z dwóch części: polskiej i niemieckiej. Część pierwsza obejmowała polskie prawo publiczne i sądowe. W przybliżeniu była to całość materiału ustawowego pisanego. Został on ułożony w porządku chronologicznym powstawania tych źródel prawa. Część polska w wyniku zatwierdzenia królewskiego uzyskała charakter zbioru urzędowego. Druga część Statutu, nieoficjalna, objęła stosowane dotąd pomniki prawa niemieckiego. Jakkolwiek praca Laskiego miała charakter tylko porządkowy, bo nie zmieniała niczego i nie dążyła do pełniejszej systematyki prawa, odegrała poważną rolę w życiu prawnym Polski, gdyż zgromadziwszy (po raz pierwszy), tak obszerny materiał prawny umożliwiała społeczeństwu zapoznanie się $\mathrm{z}$ tekstami, których przedtem nie znano, oraz stała się pobudką do prac nad unifikacją i reformą prawa. Kiedy te się nie powiodły, Statut stał się fundamentalnym zbiorem polskiego prawa ziemskiego, aż do rozbiorów Polski ${ }^{18}$.

1.6. Nowy etap prac kodyfikacyjnych rozpoczęto $\mathrm{z}$ chwilą powołania w 1520 r. przez sejm komisji złożonej $\mathrm{z}$ delegatów szlacheckich oraz wyznaczonych przez króla doktorów prawa rzymskiego i kanonicznego. Miała ona zbadać dotychczasowe prawo zwyczajowe i stanowione oraz dokonać jego głębszej przebudowy: opracować systematyczny i jednolity dla całego terytorium państwa kodeks prawa polskiego. Po dwóch latach pracy komisja opracowała $(1523 \mathrm{r}$.) reformę najpilniejszego działu prawa - postępowania sądowego, którego wady były poważniejsze niż braki prawa materialnego. Kodyfikacja ta pod nazwą Formula processus wprawdzie nie wyczerpywała w pełni prawa procesowego, ale opracowana była dobrze i zwięźle. W znacznym stopniu reformowała pod wplywem prawa rzymsko-kanonicznego dotychczasowy proces: usuwała $z$ niego nadmierny formalizm, skracała $i$ usprawniała postępowanie, wprowadzala apelację, upraszczała egzekucję wyroków, przenosząc jej ciężar z ruchomości na nieruchomości, upowszechniała pismo w postępowaniu sądowym. Kodyfikacja ta oznaczala istotny etap w rozwoju

Constitutionum, t. I: 1493-1549, vol. 1: 1493-1526, wyd. S. Grodziski, W. Uruszczak, I. Dwornicka, Warszawa 1996; vol. 2: 1527-1549, wyd. W. Uruszczak, S. Grodziski, I. Dwornicka, Warszawa 2000, s. 370.

${ }_{18} \mathrm{~J}$. L ask i, Commune incliti Poloniae Regni privilegium, constitutionum et indultum, Kraków 1506; Z. K a c z ma rczyk, O kanclerzu Janie Laskim, Warszawa 1955. 
polskiego procesu skargowego. Aż do rozbiorów Polski stanowila jedyny oficjalny kodeks sądowego prawa ziemskiego ${ }^{19}$.

1.7. Podjęte po uchwaleniu kodyfikacji procesowej prace nad reformą dalszych dziedzin prawa sądowego nie przyniosły rezultatów. W związku $\mathrm{z}$ tym na sejmie w 1532 r. powołano nową komisję w zmniejszonym składzie.

W ciągu kilku miesięcy opracowała ona i ogłosila drukiem (1532 r.) projekt pod potoczną nazwą Correctura iurium (Korektura praw). Miała ona postać całościowej kodyfikacji prawa o charakterze ogólnopaństwowym. Jej 929 artykułów podzielonych zostało na pięć ksiąg, które objęły ustrój państwa i sądów, proces, prawo prywatne (rodzinne, spadkowe, rzeczowe i obligacyjne), prawo karne oraz prawo stanów. Kompleksowy i jednolity system był niezależny od obcych wzorów, w szczególności od romanistycznych. Projekt oparty został na dotychczasowym prawie stanowionym i spisanym zwyczajowym. Oba poddano poprawie, korekturze oraz dodano wiele nowych przepisów. W rezultacie ponad połowa artykułów zawierała jakieś zmiany w stosunku do dotychczasowych rozwiązan. Całości nadano nowoczesną formę także w zakresie terminologii i języka. W sumie była to udana kodyfikacja: świadczyła o wysokim poziomie ówczesnej polskiej myśli prawniczej. $\mathrm{Z}$ powodzeniem może być porównywana $\mathrm{z}$ najwybitniejszymi ówczesnymi europejskimi osiągnięciami kodyfikacyjnymi. Ta znakomita próba kodyfikacji została jednak przez sejm odrzucona (1534 r.). Szlachta obawiała się, że wzmocni ona pozycję króla i senatu, a osłabi sejmu; poza tym przywiązana byla do stosowanych dotąd przepisów. Odrzucenie Korektury oznaczało załamanie się prac kodyfikacyjnych i zahamowanie rozwoju polskiego prawa ziemskiego na tej drodze. Dalsze próby kodyfikacyjne nie dały rezultatu. Powstawały tylko prywatne projekty kodyfikacyjne zawierające postulaty poważnych reform prawa. Następne oficjalne próby kodyfikacyjne polskiego prawa ziemskiego podjęte zostaną dopiero $\mathrm{w}$ drugiej polowie XVIII $\mathrm{w}^{20}$

1.8. W skład wielonarodowościowej Rzeczypospolitej Polski wchodzilo także Wielkie Księstwo Litewskie, które obejmowało obok właściwej Litwy i Żmudzi rozległe terytoria ruskie. W państwie tym kształtował się własny system prawa, który poza prawem zwyczajowym litewskim zawierał znaczne elementy dawnego prawa ruskiego. Od czasu unii z Polską (1385 r.) prawo WKL zaczęło stopniowo podlegać wpływom także polskiego prawa ziemskiego. Powszechne niemal w XVI w. dążności kodyfikacyjne natrafiały na Litwie na korzystniejsze niż w Koronie warunki. Dzięki temu doszło tam do całościowego skodyfikowania prawa w postaci trzech statutów (z 1529, 1566

19 Formula processus iudiciarii, wyd. O. Balzer, [w:] Corpus Iuris Polonici, t. 4, z. 1: 1523-1526, Kraków 1910; W. M a is e1, Formula processus iudiciarii - code polonais de procedure civile de 1523, Pravné-historické studie 1975, 19.

${ }^{20}$ Correctura statutorum et conseutudinem Regni Poloniae, wyd. M. Bobrzyński, SPPiPP, 1874, 3; W. Uruszczak, Korektura praw z 1532 r., t. 1-2, Warszawa 1990-1991. 
i 1588 r.), które były poprawiane i uzupełniane. Obowiązywały one na podstawie ustaw sejmowych wszystkich mieszkańców WKL - jako ogólnopaństwowe kodeksy państwa stanowego. Redagowane były w języku ruskim (starobiałoruskim), który był wówczas językiem urzędowym w WKL. Obejmowały prawo publiczne (ustrój państwa i organizację społeczeństwa) oraz prawo sądowe (cywilne, karne i procesowe). Oparte były głównie na miejscowym prawie zwyczajowym i stanowionym oraz na prawie polskim i niemieckim, a nawet wątkach prawa rzymskiego, które posiłkowo (w razie luki) mogło być wprost stosowane. Była to kodyfikacja o wyjątkowo wysokim poziomie kodyfikacyjnym w skali europejskiej; cechowal ja przejrzysty układ i precyzja sformułowań. Przethumaczono ją najpierw na łacinę (1576 r.), a potem na jezzyk polski (1614 r.). Była stosowana nie tylko na terytorium WKL, ale także $w$ rozleglych województwach wołyńskim, braclawskim i kijowskim, wcielonych przy zawieraniu unii lubelskiej $(1569$ r.) do Korony. Posilkowo korzystano $z$ niej równiez w Koronie w XVII i XVIII w. (zwłaszcza w Małopolsce). Wywarła także duży wpływ na kodyfikacje rosyjskie i środkowoeuropejskie. Na ziemiach WKL obowiązywała aż do $1840 \mathrm{r}^{21}$

1.9. Trzeci czlon wielkiej dawnej Rzeczypospolitej - Prusy Królewskie - także doczekal się kodyfikacji pod nazwą Korektury pruskiej, zatwierdzonej przez sejm w 1598 r. Oparta byla na prawie koronnym (ziemskim), chociaż nie zawsze ściśle, a także na prawie rzymskim. Nie była to jednak kodyfikacja pełna. Regulowala przede wszystkim ustrój sądów i prawo procesowe oraz część prawa prywatnego (głównie rodzinne i spadkowe). W innych dziedzinach szlachte pruską nadal obowiązywało prawo chelmińskie, które od dekretu króla Kazimierza Jagiellończyka (1476 r.) stosowane było wobec wszystkich mieszkańców Prus Królewskich. Korektura pruska dzięki swemu precyzyjnemu ujęciu oraz wpływom prawa koronnego wykorzystywana była pomocniczo

${ }_{21}$ J. B ardach, Geneza romanizacji II Statutu litewskiego, [w:] Dawne prawo [...] Bartla, Kraków 1995, s. 191-206; te nże, Prawo litewskie w Koronie Królestwa Polskiego XVII i XVIII w., [w:] Kultura Litwy i Polski w dziejach, Kraków 2000, s. 51-65; t e nże, La Romanité dans les codifications lituaniennes á l'époque de la Renaissance, [w:] Le droit romain, Warszawa 1996, s. 69-81; tenże, Les Statutus Lituaniens - codifications de l'époque de Renaissance, [w:] La codification européenne du Moyen - Age au siécle des Lumieres, Warszawa 1997, s. 103; t e nże, Statuty litewskie a prawo rzymskie, Warszawa 1999, s. 160; t e nże, Statuty litewskie w Koronie Królestwa Polskiego, [w:] SDPiPP, t. 4, Lódź 1999, s. 17-18; t e $\mathrm{n} \dot{z}$ e, Wplyw prawa rzymskiego na Statuty litewskie oraz ich oddzialywanie na kraje sqsiednie, Lithuania 1997, 8, nr 1-2, s. 12-26; S. G od e k, Kilka uwag o badaniach nad romanizacja Statutów litewskich, Zesz. Pr. (UKSW) 2002, 2, z. 2, s. 171-181; S. Ła zutk a, Lietuvos statutai ju kuréjai ir epocha, Kaunas 1994, s. 47; I. Valik on y té i in., Primatis Lietuvos Statutas, Vilnius 2001, s. 382; A. B. Zakrzewski, Paradoksy unifikacji prawa $i$ ustroju Wielkiego Ksiestwa Litewskiego i Korony XVI-XVIII w., CPH 1999, 51, z. 1-2, s. 219-238; zob. też S. P laza, Historia prawa w Polsce na tle porównawczym, cz. 1: X-XVIII w., Kraków 1997, s. 124, 161-166. 
w sądach koronnych aż do początku XIX w. ${ }^{22}$ Oznaczało to, że razem ze statutami litewskimi przytłaczająca większość terytoriów wielonarodowościowej Rzeczypospolitej szlacheckiej posiadała od XVI w. skodyfikowane prawo na większą skalę, a przy tym powszechne i na wyjątkowo wysokim poziomie, co w ówczesnej Europie było jeszcze rzadkością ${ }^{23}$.

1.10. Wiek XVIII uchodzi za wiek kodyfikacji, ale ruch kodyfikacyjny na dobre rozpoczął się dopiero $w$ drugiej polowie tego stulecia. W ten ruch włączyła się również Polska, kierując się analogicznymi, jak w innych krajach, założeniami kodyfikacyjnymi, które uwzględniały idee przewodnie Oświecenia, oparte na prawie natury oraz postulatach szkoły humanitarnej w zakresie prawa karnego ${ }^{24}$.

Powolana w 1776 r. przez sejm komisja kodyfikacyjna opracowała w 1778 r. projekt pod nazwą Zbioru praw sqdowych. Podstawowym tworzywem projektu było wprawdzie dotychczasowe prawo, ale zostalo ono zreformowane i uzupełnione nowymi treściami, jakie rozwijały ówczesne kodyfikacje europejskie. Projekt obejmował wszystkie działy prawa sądowego wraz $\mathrm{z}$ regulacją niektórych stosunków społecznych i politycznych oraz kościelnych. Zbiór przewidywal znaczny zakres powszechności swych norm: mieli mu podlegać członkowie wszystkich stanów w zakresie prawa karnego i procesowego oraz obligacyjnego, a chłopi - nadto w dziedzinie stosunków rodzinnych i spadkowych. Najwięcej zmian w kierunku postępowym przewidywał projekt $w$ dziedzinie prawa cywilnego, natomiast $w$ prawie karnym pozostawial w dużej mierze stare feudalne pojęcia $\mathrm{i}$ instytucje prawne. Chociaż był to projekt umiarkowany, to pod naciskiem kół zachowawczych szlachty $\mathrm{i}$ du-

${ }^{22}$ Zob. przyp. nr 5.

${ }^{23} \mathrm{~S}$. S a lm on ow icz, Narodziny nowożytnej myśli kodyfikacyjnej $w$ Europie, [w:] t e nż e, Studia, Toruń 1995, s. 76-100; te nż̇, Die Neuzeilliche Europäische Kodifikation (16-17 Jahrhundert). Die Lehre und Ihre Verwirklichung, [w:] La codification..., s. 35-68; K. S ó j k a - Zielińska, Le role des juristes dans le movement de la codification du droit en Polgne á l'époque de la Renaissance, [w:] La codification..., s. 143-155; W. U r u sz c za k, Les codes de droit en Europe á l'époque de la Renaissance, [w:] La codification..., s. 69-102; t e nże, Europejskie kodeksy prawa doby renesansu, CPH 1988, 40, z. 1; t e nże, La typologie de codes de droit parus en Pologne á l'époque de la Renaissance, [w:] Historia integra [...] prof. S. Salamonowiczowi, s. 285-302; t en ż e, Udzial duchowieństwa w kodyfikacji prawa polskiego w pierwszej polowie XVI w., [w:] Divina humana. Ksiega [...] prof. H. Misztala, Lublin 2001, s. $297-311$.

${ }^{24}$ E. B ork ow sk a - B a g i eń sk a, Między zbiorem a kodeksem. Refleksje o kodyfikacji i myśli kodyfikacyjnej Oświecenia, [w:] Historia integra [...] prof. S. Salmonowiczowi, s. 85-94; J. Michalski, Problematyka reformy sqdownictwa $i$ prawa sqdowego $w$ okresie sejmu delegacyjnego lat 1767-1768, CPH 2002, 54, z. 2, s. 21-41; t e nże, Zagadnienie reformy sqdownictwa i prawa sqdowego w poczqtkach panowania Stanislawa Augusta, CPH 2000, 52, z. 1-2, s. 67-107; S. S a $1 \mathrm{~m}$ on ow ic z, $Z$ wieku Oświecenia. Studia $z$ dziejów prawa i polityki XVIII w., Toruń 2001, s. 121; K. Sójka-Zielińska, Le mouvement de la codification du droit en Pologne au XVIII siécle, [w:] La codification..., s. 207-215. 
chowieństwa oraz ambasady rosyjskiej został zdecydowanie odrzucony przez sejm 1780 r. jako zbyt radykalny ${ }^{25}$.

1.11. Myśl skodyfikowania prawa sądowego podjęto ponownie dopiero na Sejmie Czteroletnim, który w Konstytucji 3 Maja przewidywał opracowanie Kodeksu Stanisława Augusta, obejmującego całość norm prawa cywilnego, karnego i procesowego. Prace nad nim podjęły $\mathrm{z}$ polecenia sejmu dwie komisje: dla Korony i dla Litwy. Dzieła swego, poważnie zaawansowanego, komisje nie doprowadzily do końca $\mathrm{z}$ powodu wybuchu wojny z Rosja $(1793$ r.). Zdołały jednak przygotować cenne materiały w postaci projektów poszczególnych części kodeksu. Miały one bardziej nowoczesny charakter niż Zbiór praw i Konstytucja 3 Maja. Widać to zwłaszcza $w$ zakresie prawa karnego, gdzie przewidywano szereg już humanitarnych zasad. Gdyby kodeks opracowany został do końca, to Rzeczpospolita otrzymałaby kodyfikację karną, którą można by zestawiać $\mathrm{z}$ najnowocześniejszymi osiągnięciami europejskimi $w$ tej dziedzinie, $i$ to w sytuacji, kiedy większość krajów miała jeszcze bardzo zacofane prawo karne $^{26}$.

\section{2}

2.1. Prawo prywatne (cywilne) europejskiego kontynentu, zwłaszcza krajów zachodnio- i środkowoeuropejskich, rozwijało się w X-XVII w. nie w sposób odizolowany $w$ poszczególnych państwach, ale przeciwnie - oparte na wspólnych podstawach i przy wzajemnym oddzialywaniu. Przede wszystkim kraje te należaly do tego samego kręgu kultury prawnej. Po drugie - w większości z nich rozwój prawa prywatnego odbywał się pod wpływem (mniejszym lub większym) wspólnych czynników - tj. średniowiecznej nauki prawa rzymskiego i kanonicznego, które miały charakter uniwersalistyczny, oraz nowożytnej idei prawa natury. $\mathrm{Na}$ tej podstawie kształtowała się unifikacja podstawowych pojęć i zasad prawnych, jakby trzon prawa o zasięgu powszechnym, oraz rozwijała się jednolita w swych podstawach nauka prawa prywatnego. W ramach tej pewnej całości wzrastały jednak autonomiczne

${ }^{25}$ Zbiór praw sqqdowych przez Andrzeja Zamoyskiego ulożony, wyd. W. Dutkiewicz, Warszawa 1874; E. B or k ow sk a - B a gi eńs k a, Zbiór praw sqdowych Andrzeja Zamoyskiego, Poznań 1986; zob. też S. Płaz a, Historia prawa..., s. 203.

${ }^{26}$ Kodeks Stanislawa Augusta. Zbiór dokumentów, wyd. S. Borowski, Warszawa 1938; A. Lityński, Der Entwurf des Stanislaus-August-Gesetzbuches (1791-1792), [w:] La codification..., s. 217-225;

T. Maciejewski, Deputacja litewska dla opracowania Kodeksu Stanislawa Augusta (1791-1792), [w:] Materialy z V Miẹdzynarodowej Konferencji „Nauka i jakość życia”, Wilno 1998, s. 12-20; W. Szafránski, Kodeks Stanislawa Augusta - stan badań, [w:] Przez Tysiqclecia, t. 2, Katowice 2001, s. 42-52; te nże, Nieznane materialy do dziejów tzw. Kodeksu Stanislawa Augusta, CPH 2000, 52, z. 1, s. 251-257. 
systemy narodowe. Do nich w szczególności należało polskie prawo ziemskie, które miało charakter rodzimy ${ }^{27}$.

Polacy w średniowieczu obawiali się prawa rzymskiego jako prawa cesarskiego, by w ślad za nim nie narzucono im zwierzchnictwa cesarskiego. W czasach nowożytnych szlachta także sprzeciwiała się jego wprowadzeniu, sądziła bowiem, że prawo to, przyznając królowi pełnię władzy, sprzyjać będzie królewskim tendencjom absolutystycznym, co zagrażałoby jej wolnościom i przywilejom. W związku z tym prawo rzymskie miało tylko niewielki bezpośredni wpływ na polskie prawo ziemskie. Natomiast w prawie miejskim doszło do znacznej recepcji prawa rzymskiego; do praktyki sądowej miejskiej przenikało ono głównie dzięki literaturze prawniczej ${ }^{28}$.

2.2. Prawo prywatne obejmowało prawo osobowe, prawo małżeńskie, rodzinne i opiekuńcze, prawo rzeczowe, prawo spadkowe i prawo zobowiązań. Taki wszakże podział wprowadza dzisiejsza nauka; wspólcześni stosowali inny - zresztą nie przywiązywali do tej kwestii większej wagi. Spośród stanowych praw prywatnych w Polsce największe znaczenie miało prawo ziemskie.

2.3. Do najważniejszych zaś działów prawa ziemskiego należało prawo rzeczowe, które obejmowało posiadanie ${ }^{29}$, prawo własności ${ }^{30}$ oraz ograniczone

${ }^{27} \mathrm{~K}$. S ój k a - Zi e li ńs $\mathrm{k}$ a, Les fondements idéologiques de la codification du droit civil a l'époque de Lumiéres, [w:] Evolution, Lublin 2000, s.105-115; W. U r u s z c z a k, Między partykularyzmem a unifikacjq. Prawo polskie ziemskie w XIV-XV w., [w:] Partykularyzm a unifikacja, Gdańsk 1994, s. 9-29; zob. też S. Płaza, Historia prawa..., s. 206-211.

${ }^{28} \mathrm{~J}$. B a rdach, Le modèle romain et la Republique Polono-Lithuanienne aux temps de la Renaisance (XVIe siécle), [w:] Au-Delà des frontières Mélalanges des droit romain offerts à W. Wolodkiewicz, Warszawa 2000, s. 45-56; S. Godek, Prawo rzymskie w dawnej Rzeczypospolitej. Przeglad stanu badań, CPH 2001, 53, z. 2, s. 27-84; t e n ż e, Spór o znaczenie prawa rzymskiego w dawnej Rzeczypospolitej, CPH 2002, 54, z. 1, s. 105-141; S. S a 1m on owicz, $O$ badaniach nad rolq prawa rzymskiego $w$ Polsce slów kilka, CPH 2002, 54, z. 2, s. 469-470; J. S o nd el, Elementy prawa rzymskiego $w$ miejskim prawie karnym $w$ dawnej Polsce, [w:] Prof. J. Kodrębskiemu in memoriam, Lódź 2000, s. 375-398; t en że, Kodeks Justyniana jako podstawa prawna $w$ postepowaniu sqdowym $o$,crimen laese maiestatis" $w$ osiemnastowiecznej Polsce, Nowy Filomata 2000, 4, nr 2, s. 143-147; tenże, Prawo rzymskie jako podstawa projektów kodyfikacyjnych $w$ dawnej Polsce, Zesz. Praw. [UKSW] 2001, 1, s. 47-69; te n ż e, Prawo rzymskie w procesie sprawców porwania Stanislawa Augusta, [w:] Crimina, Lublin 2001, s. 191-200; t e n ż e, Rola prawa rzymskiego w ksztaltowaniu polskiej kultury prawnej, [w:] Tradycje antyczne, Warszawa 1995, s. 47-69; K. Só j k a - Zi i li ń s k a, Le droit romain et l'idée de codification du droit privé au siécle des Lumières, [w:] La codification..., s. 251-265; zob. też S. Płaza, Historia prawa..., s. 95, 132.

${ }^{29}$ F. L ong champs de Béri e r, Posiadanie a wlasność - nad uwagami św. Tomasza, Zesz. Praw. [UKSW] 2002, 2, s. 59-70; zob. też S. Pła za, Historia prawa..., s. 262.

${ }^{30} \mathrm{~F}$. Leśniak, Zarys problematyki dóbr stolu królewskiego $w$ Koronie $i$ na Litwie (koniec XVI-XVIII w.), Rocz. Nauk.-Dyd. WSP Kr. 1999, 205, Pr. Hist. 20, s. 29-44; H. O ls z e w s k i, Uwagi o wlasności $w$ ideologii demokracji szlacheckiej, CPH 2004, 56, z. 1, s. 193-206; Z. R a u, Wlasność $w$ doktrynie politycznej Johna Lock, CPH 2004, 56, z. 1, s. 204-214; 
prawa rzeczowe (jak: użytkowanie ${ }^{31}$, służebności, zastaw, hipoteka). Wszystkie odnosily się przede wszystkim do nieruchomości - ziemi, która stanowiła podstawę stosunków gospodarczo-społecznych w epoce feudalnej. W przeciwieństwie do krajów zachodnioeuropejskich, gdzie przeważała lenna własność ziemi podporządkowana władztwu prawnemu seniora, co tworzyło hierarchiczny ustrój własności ziemskiej ${ }^{32}$, w Polsce regułą była alodialna własność feudałów, czyli wolna, niepodlegająca takim ograniczeniom ${ }^{33} . \mathrm{Z}$ uwagi na wspomniane znaczenie ziemi najbardziej rozbudowane były przepisy związane z jej obrotem, który został poddany kontroli władzy. Rychło pojawiła się nowoczesna zasada (od końca XIV w.), że umowa kupna-sprzedaży nieruchomości rodzi tylko zobowiązanie do przeniesienia prawa własności, które przechodzi na nabywce dopiero w wyniku wpisu tej umowy do księgi sądowej ${ }^{34}$.

K. Sójka-Zielińska, L' Expropriation en Pologne ( $X V T^{e}-X I X^{e}$ siecles), [w:] Recueils d. I Societé Jean Bodin pour L'Hist. Compar d. Inst. 2000, T. 67, s. 321-334; T. S zu 1 c, Dyspozycja królewska domenq ziemskq w świetle konstytucji sejmów egzekucyjnych, [w:] Symbolae historico-iuridicae Lodzienses Julio Bardach dedicatae, Lódż 1997, s. 144-154; t e n ż e, Z badań nad egzekucja praw. Podstawy ustawodawcze egzekucji dóbr, ich interpretacja i nowelizacja na sejmach panowania Zygmunta II Augusta, Lódż 2000; zob. też S. Pła z a, Historia prawa..., s. $272-273$.

${ }^{31}$ A. Gry pu ć, Użytkowanie puszcz królewskich przez ludność wiejskq w świetle „Ustawy na wloki" oraz "Ustawy leśnej" z 1567 r., [w:] Spoleczeństwo i polityka do XVII w. Ksiega pamiatkowa [...] prof. W. Odyńca, Olsztyn 1994, s. 119-122.

${ }^{32} \mathrm{~S}$. Gawlas, Dlaczego w Polsce nie bylo feudalizmu lennego, [w:] Feudalizm w Europie, Poznań 1998, s. 101-125; T. Ju rek, Omagralitas alias manowstwo. Przyczynek do dziejów recepcji prawa lennego w średniowiecznej Wielkopolsce, [w:] Kościót [...] Studia [...] prof. S. Trawkowskiemu, Warszawa 2000, s. 259-271; J. K oc h a n o w i c z, Czy w Polsce nowożytnej byl feudalizm?, [w:] Feudalizm w Europie, s. 187-202; K. Kow al e w sk i, Powstanie systemu lennego w domenie monarszej ostatnich Przemyślidów i pierwszych Luksemburgów, Rocz. Dziej. Spol. Gospod. 1996-1997, 56-57, s. 5-28; A. M ą cza k, Feudalizm w I Rzeczypospolitej. Wieloznaczność terminu i ewolucja zjawiska, [w:] Feudalizm w Europie, s. 177-185; G. R u t k ow sk a, Nadania ziemi w zamian za obowiqzek obrony wielkopolskich warowni ( $w$ siwietle dokumentów Wladyslawa III i Kazimierza Jagiellończyka), [w:] Homines et societas [...] Studia [...] ofiarowane A. Gasiorowskiemu, Poznań 1997, s. 277-284.

${ }^{33}$ W. B o bińsk i, Województwo kijowskie w czasach Zygmunta III Wazy. Studium osadnictwa i stosunków wlasności ziemskiej, Warszawa 2000, s. 599; J. D ł u g o s z, Latyfundium Lubomirskich w XVII w. (powstanie, rozwój, podzialy), Opole 1997; J. K u r t y k a, Posiadlości, dziedziczność i prestiż, Badania nad późnośredniowiecznq $i$ wczesnonowożytnq wielkq wlasnościq możnowladczq w Polsce XIV-XVII w., RH 1999, 65, s. 161-194; K. Pr z y b oś, Wielka wlasność ziemska ziemi przemyskiej $i$ sanockiej $w$ drugiej polowie XVII w., [w:] Sqsiedztwo, Rzeszów 1997, s. 79-101; J. J. S k o m i a ł, Z problematyki wlasności w ,Kronice polskiej" Wincentego zwanego Kadlubkiem (ok. 1150-1223), CPH 2004, 56, z. 1, s. 177-184; B. S1iwinsk i, Rozwój wlasności rycerskiej w poludniowej części Kujaw Inowroclawskich w XII i XIII w., Ziem. Kuj. 1993 , 9, s. $45-75$.

${ }^{34}$ J. D u m a n ow ski, Mechanizmy szlacheckiego obrotu ziemiq na Kujawach w drugiej polowie $X V I$ w. $w$ świetle ksiqg brzesko-kujawsich, Zap. Kuj.-Dobrz. 1995, 9, s. 55-65; M. K u 1 e ck i, Problem wieczystości wpisów w aktach urzędowych na terytorium Korony w epoce staropolskiej, Radca Prawny 1998, nr 1, s. 56-60. 
Bardzo rozbudowane zostało prawo zastawu, zwłaszcza bez dzierżenia, czyli hipoteka dla zabezpieczenia długoterminowych pożyczek. Została ona już od końca XVI w. oparta na ustawowych, nowoczesnych zasadach - takich, które w wielu krajach pojawily się dopiero w końcu XVIII w. ${ }^{35}$

2.4. W skali Europy zasady dziedziczenia były bardzo zróżnicowane. W każdym niemal kraju wykazywały one pewne różnice. Po drugie - zasady te były różne dla poszczególnych stanów: inne dla feudałów, inne dla mieszczan, inne dla chłopów. Po trzecie - zależały od płci: kobiety były wyraźnie upośledzone, początkowo $\mathrm{w}$ ogóle były wykluczone od dziedziczenia, potem dopuszczano je do dziedziczenia ruchomości, w końcu w ograniczonym zakresie do nieruchomości. Nadto inne reguły obowiazywały przy spadkobraniu ruchomości, a inne - przy nieruchomościach, przy czym tu jeszcze rozróżniano dobra dziedziczne i dobra nabyte oraz lenne. Wreszcie istotny byl czynnik ewolucji: nowożytne prawo spadkowe w wielu wypadkach wyraźnie odbiegało od średniowiecznego. Ta różnolitość dotyczyła także Polski ${ }^{36}$.

Ewolucja prawa spadkowego była wynikiem przede wszystkim ścierania się dziedziczenia beztestamentowego ( $\mathrm{z}$ mocy prawa, ustawowego) $\mathrm{z}$ testamentowym. W Europie zachodniej następowal rozwój dziedziczenia testamentowego, co było związane z powiększającą się swobodą dysponowania majątkiem w ogóle; natomiast w Polsce doszło do jego znacznego zahamowania, zwłaszcza w prawie ziemskim: od początku XVI w. szlachta polska w ogóle nie mogła rozporządzać swymi dobrami w testamencie. Poza tym polskie prawo ziemskie w zasadzie nie przewidywało dziedziczenia po sobie małżonków. W innych krajach, chociaż powoli, takie prawo się rozwijało. Podobnie było $w$ polskim prawie miejskim ${ }^{37}$.

${ }^{35}$ C. Dziem in iczuk, Problem zastawu Elblaga $w$ XVII-XVIII w. Zarys historyczno-prawny, [w:] Miscellanea [...] In memoriam I. Kwiatkowska-Malinowska, Białystok 1999, s. 17-33; S. Grodziski, Z dziejów spiskiego zastawu uwag kilka, [w:] SDPiPP, t. 4, Lódź 1999, s. 67-77; J. P a ku1ski, Jeszcze o zastawie Zlotoryi i Ziemi Dobrzyńskiej krzyżakom przez Wladyslawa Opolczyka w latach 1391-1392, Zap. Kuj.-Dobrz. 1995, 9, s. 11-30; M. R a d o ch, Dlugi zastawne Siemowita IV Mazowieckiego wobec Zakonu Krzyżackiego, [w:] Spoleczeństwo i polityka do XVII w. Ksiega pamiqtkowa [...] W. Odyńca, Olsztyn 1994, s. 51-57; M. S e p i a 1, Zastaw na dobrach ziemskich $i$ dochodach królewskich $w$ okresie panowania Wladyslawa III Warneńczyka na Wegrzech (1440-1444), [w:] Ku zjednoczonej Europie, Kraków 1997, s. 135-149; H. Zaremska, Rzecz skradziona w żydowskim zastawie, [w:] Kościól. Kultura [...] Studia [...] S. Trawkowskiemu, Warszawa 2000, s. 337-350; zob. też S. P ł a z a, Historia prawa..., s. 293-294.

${ }^{36} \mathrm{E}$. Kizi k, Pośmiertny inwentarz gdánskiego kramarza korzennego mennonity Hendrika van Dührena z 1694 r., Almanach Hist. 2000, 2, s. 185-208; J. M a t u s z ew s ki, Morbus comitialis czyli kaduk, [w:] te nże, Pisma, t. 2, Łódź 2000, s. 331-349; A. Pośpiech, Pulapka rzeczywistości. Pośmiertne spisy ruchomości szlachty wielkopolskiej z XVII w., Warszawa 1992; Pośmiertny inwentarz Ludwiki Marii Gonzagi, 1667 r., wyd. P. Szmydka, Rocz. Warsz. 1993, 23, z. 2, s. 61-296; zob. też S. Płaza, Historia prawa..., s. 306-309.

${ }^{37}$ R. D emb k ka, O testamencie w polskim prawie średniowiecznym, [w:] Studia z historii [...] Ksiega dedykowana prof. J. Walachowiczowi, Poznań 2002, s. 57-71; D. G łówk a, Podstawy 
3.1. Przez dhugie wieki nie rozróżniano prawa karnego od cywilnego; nie wyodrębniano bezprawia karnego od cywilnego (np. kradzieży rzeczy od nieoddania długu). Proces wyodrębniania się prawa karnego od cywilnego rozpoczął się (zwłaszcza na zachodzie Europy) już od XII w. W Polsce trwał on aż do rozbiorów.

3.2. Średniowieczne prawo karne przez wiele stuleci było oparte na zwyczajowym prawie germańskim oraz słowiańskim. Dopiero z czasem nawiązywało do tradycji rzymskiego prawa karnego oraz poddawało się wpływom prawa kanonicznego. Europejskie monarchie stanowe w XIV-XV w. podjęły dążenia unifikacyjne $\mathrm{w}$ zakresie prawa karnego. W ich wyniku powstawało we Włoszech prawo statutowe, które odegrało ogromną role w rozwoju europejskiego prawa karnego w ogóle. W Anglii kształtowało się common law obejmujące także prawo karne, które zresztą obowiązywało wszystkich mieszkańców kraju. W Niemczech słynna Karolina (1532 r.) stała się podstawowym źródłem prawa karnego, doprowadzając do jego ujednolicenia i unowocześnienia. Wywarła ona także wielki wpływ na rozwój prawa karnego w innych krajach europejskich. W krajach słowiańskich, w tym i w Polsce, prawo karne rozwijało się na podstawie rodzimych pierwiastków, wyjąwszy prawo miejskie, które opierało się na źródłach niemieckich, w szczególności na Karolinie ${ }^{38}$.

Rozwój ustrojów absolutnych (od końca $\mathrm{XV}$ w.) dał poważny impuls do podjęcia kodyfikacji prawa karnego. Władca absolutny dla „dobra poddanych" zmierzal do wprowadzenia jednolitego prawa, także karnego, dla calego kraju i w zasadzie dla wszystkich jego mieszkańców (ale bez zasady równości) w celu zaprowadzenia powszechnego ładu oraz podporządkowania sobie również tą drogą życia i działalności całego społeczeństwa. Ukazał sie zatem szereg kodyfikacji, bądź poświẹconych tylko prawu karnemu, bądź w szerszym zakresie ${ }^{39}$. W Polsce nie było ono osobno skodyfikowane.

prawne testamentów $i$ inwentarzy pośmiertnych duchowieństwa katolickiego $w$ Polsce $w$ epoce potrydenckiej, Archael.-Hist. Pol. 1997, 5, s. 203-210; T. M a ci e je w sk i, Dziedziczenie testamentowe w prawie miast pruskich, [w:] Prawo wczoraj $i$ dzis. Studia dedykowane prof. K. Sójce-Zielińskiej, Warszawa 2000, s. 173-188; Z. R y mas z ew sk i, Klopoty Gdańska $z$ kadukami królewskimi. (Koniec XVI-poczqtek XVIII stulecia), [w:] Historia integra [...] prof. S. Salmonowiczowi, s. 233-248; Testamenty mieszczan wojnickich, wyd. P. Dymek, Wojnicz 1997; Testamenty szlachty krakowskiej XVII-XVIII w. Wybór tekstów źródlowych $z$ 1650-1799, opr. A. Falniowska-Gradowska, Kraków 1997.

${ }^{38}$ M. Mikolajczy y, Przestepstwo i kara w prawie miast Polski poludniowej $w$ XVI-XVIII w., Katowice 1998, s. 300; zob. też S. Płaz a, Historia prawa..., s. 334-335., 342-347.

${ }^{39} \mathrm{Y}$. Cartnyvels, D'ou vient le code pénal? Une approche généalogique des premiers codes pénaux au XVIIr, Paris 1996; A. Lit y ńs ki, Między realizmem a utopiq. Rzecz o humanitarys- 
Wszakże kodyfikacje o szerszym zasięgu oraz ich projekty poświęcały mu niekiedy wiele miejsca, a ostatnia próba kodyfikacji (lata 1791-1792) przygotowywała już nowoczesne prawo karne ${ }^{40}$.

3.3. Nauka prawa karnego najwcześniej (już od XIII w.) zaczęła rozwijać się we Włoszech, ale w skali całej Europy nie budziła pogłębionych zainteresowań teoretycznych, pozostając aż po XVIII stulecie w cieniu nauki prawa prywatnego (cywilnego). Pewien wyjątek stanowily tylko ożywione komentarze Karoliny. W Polsce nauka ta była słabo rozwinięta. Wskutek tego bardzo powolny był w calej Europie rozwój pojęć ogólnych z zakresu prawa karnego. Pierwsze próby wyodrębnienia tych pojęc pojawily się dopiero pod koniec średniowiecza w doktrynie włoskiej, ale nie stworzyła ona jeszcze spójnego systemu. Te ogólne pojęcia pojawiły się w formie odrębnej części wstępnej w kodeksach karnych dopiero pod koniec XVIII $w^{41}$

3.4. Polskie prawo karne ziemskie rozwijało się samodzielnie, głównie w drodze praktyki i zwyczaju, nie podlegając poważniejszym obcym wpływom. W porównaniu $\mathrm{z}$ innymi krajami było na ogól słabo rozwinięte ${ }^{42}$.

3.5. Przez wiele stuleci prawo europejskie i polskie nie znalo ogólnej definicji przestępstwa. Określano je w sposób materialny - jako czyn niedozwolony. Dzielono je na prywatne i publiczne. Krąg prywatny przestępstw wyznaczała zasada prywatnoprawna; wyrządzały one szkodẹ lub krzywdę jednostce; sprawiedliwości dochodzil pokrzywdzony na podstawie prywatnej skargi w sądzie. Kara miala charakter prywatny. Krąg przestępstw publicznych

tach Oświecenia, [w:] Studia $z$ historii państwa, prawa $i$ idei. Prace dedykowane prof. J. Malarczykowi, Lublin 1997, s. 231-250; t e nz e, Trzy rewolucje w prawie karnym u schylku XVIII wieku: lata 1791-1792 nad Sekwana, Dunajem i Wisla, [w:] Historia - idee - polityka. Ksiega dedykowana prof. J. Baszkiewiczowi, Warszawa 1995, s. 65-95.

${ }^{40} \mathrm{M}$. A f f e k, Idee humanitarne $w$ czasopismach polskiego Oświecenia, Analecta St. Mem. z Dz. Nauki 1995, nr 4, z. 2, s. 43-54; A. Litýn ski, O nowej filozofii prawa karnego w Rzeczypospolitej czasów stanislawowskich uwag kilka, [w:] Dyplomacja, polityka, prawo. Ksiega [...] ofiarowana prof. $H$. Kocójowi, Katowice 2001, s. 243-252; t e nże, $O$ prawie karnym insurekcji 1794 r., [w:] 200 rocznica powstania kościuszkowskiego, Katowice 1994, s. 159-169; t e nże, O reformie prawa w Polsce pod koniec XVIII $w$. (Wybrane zagadnienia karnomaterialne), [w:] Prawo a dzieje państwa, Białystok 1996; t e nz ze, The Reform of Criminal Law during the Four-Year Diet, [w:] Constitution, Indianopolis 1997, s, 397-421; t e n że, $U$ progu reform Sejmu Czteroletniego: polskie prawo karne materialne, [w:] Studia z historii [...] prof. J. Walachowiczowi, s. 161-174; M. Mikolajczyk, Prawo karne materialne w ustawach sejmowach $w$ Polsce XVIII w., [w:] Parlamentaryzm [...] prace dedykowane prof. S. Plazie, Kraków 1999, s. 197-209; Z. Naw orsk i, Prawo karne i proces Polski przedrozbiorowej, Torun 1994; S. S a 1 o m on ow i cz, Cesare Beccaria und die Strafrechtsreform in Polen im 18. Jahrhundert, Comp. Law Rev. 1996, 7, s. 91-104.

${ }^{41}$ K. Sójka-Zielińsk a, Prawa karne $w$ dzielach Karola Koranyiego, [w:] Karol Koranyi, Torun 1998, s. 39-52.

${ }^{42}$ A. Lit y ński, $Z$ badań nad reformq prawa karnego u schylku Pierwszej Rzeczypospolitej, [w:] Trudne stulecia. Studia [...] ofiarowane prof. J. Michalskiemu, Warszawa 1994, s. 152-161; zob. też S. P 1aza, Historia prawa..., s. 350, 351. 
wyznaczała zasada publicznoprawna; godziły one w interes społeczny, porządek publiczny - także wtedy, gdy skierowane były tylko przeciwko osobom prywatnym. Ścigane były przez organy państwa, a kary miały charakter publiczny ${ }^{43}$.

Zasada prywatnoprawna dominowała od najdawniejszych czasów. W Polsce utrzymała się aż do rozbiorów. W drugiej połowie XVIII w. stopniowo jednak ją ograniczano. Natomiast zasada publicznoprawna zwyciężyła ostatecznie krajach europejskich już od XVI w., co było związane z ksztaltowaniem się ustroju absolutnego, który każde przestępstwo traktowal jako publiczne.

Brak było jednak ścisłego określenia przestępstw i dokładnego oznaczenia ich kręgu, co prowadziło do dowolnego stosowania prawa karnego i popełniania niejednokrotnie wielkich nadużyć, zwłaszcza w państwach o ustroju absolutnym. W szczególności dopuszczalne było to na zasadzie analogii - tj. uznania za przestępstwo czynu podobnego do zakazanego przez prawo (stanowione lub zwyczajowe). Dlatego doktryna humanitarna prawa karnego (druga połowa XVIII w.) ostro potępiła taki sposób podejścia do rozumienia przestępstwa. Wysunęła postulat formalnej definicji przestępstwa, ujmowanej w formule nullum crimen sine lege (nie ma przestępstwa bez ustawy), co wykluczało dotychczasową arbitralność i stosowanie analogii. Takie ujęcie przestępstwa pojawiło się w kodeksach karnych od końca XVIII w., w szczególności w polskim kodeksie karnym wojskowym z 1775 r., częściowo w projektach kodyfikacyjnych z lat 1778 i 1792; w obszernej ustawie o sądach sejmowych z 1791 r. polscy karniści wyprzedzili pod tym względem nawet austriackich (Józefina z 1787 r.) $)^{44}$.

3.6. Od początku czasów nowożytnych w Europie i w Polsce (w prawie miejskim i wiejskim) szeroko rozprzestrzenily się ,polowania na czarownice”, które trwały prawie przez trzy wieki i w skali Europy pochłonęły do 200 tys. niewinnych ofiar. Czary zaliczano do zbrodni obrazy majestatu boskiego

${ }^{43}$ P. Bla stebrei, Kriminalität in Rom 1560-1585, Tübingen 1995; Crime, Society and the Law in Renaissance Italy, wyd. T. Dean, K. J. Lowe, Cambridge 1994; K. B a r a n, Dzieje przestępstw politycznych w Anglii: Między średniowieczem a wspólczesnościq, Kraków 2000; M. L. K lement ow ski, Zmiany zasad odpowiedzialności karnej $w$ prawie niemieckim do Constitutio Criminalis Carolina z 1532 r., Rejent 1997, nr 10, s. 22-43.

${ }_{44}$ M. B oguck a, Law and Crime in Poland in Early Modern Times, Acta Pol. Hist. 1998, 77, s. 59-77; A. Kar piński, Przestepczość we Lwowie w końcu XVI i w XVII w., Przegl. Hist. 1996, nr 87, z. 4, s. 753-768; M. Mikołajczyk, Przestepstwa przeciwko religii $i$ Kościolowi $w$ prawie miast polskich od XVI do XVIII w., CPH 2000, $\mathrm{nr} 52, \mathrm{z} .1-2$, s. 225-238; S. Milewski, $W$ świecie wystẹpku $i$ zbrodni. $Z$ dziejów przestepczości $i$ jej zwalczania, Warszawa 1996; W. Organiści a k, Rodzaje przestepstw w kodyfikacji prawa wojskowego Rzeczypospolitej szlacheckiej z 1775 r., Probl. Pr. Kar. 2001, nr 24, s. 202-219; P. W i ą zek, Klasyfikacja przestepstw w ordynacji ziemskiej księstwa opolsko-raciborskiego $z$ r. 1562, Acta Univ. Wrat. 1998, 2070, Prawo 261, s. 83-96. 
i karano $\mathrm{z}$ reguły spaleniem na stosie po przeprowadzeniu wymyślnych tortur, które miały skłonić czarownicę do przyznania się i ujawnienia wspólniczek, dzięki czemu okazywało się czasem, że były nimi wszystkie kobiety danej wsi. W Europie największe nasilenie walki z czarownicami przypadło na XVII w. W Polsce te procesy rozpoczeły się w XVI w., ale początkowo oskarżone karane były lagodnie, rzadko karą śmierci. Na szerszą skalę represję karną za czary zaczęto stosować w XVII w. i w pierwszej połowie XVIII w., zwłaszcza w małych miasteczkach i wsiach, ale nie przybrała ona takich rozmiarów, jak w innych krajach europejskich. Ponadto nierzadko orzeczona kara śmierci nie byla wykonywana. W Polsce (Korona) w XVI-XVIII w. sądzonych było ok. 10 tys. kobiet, ale w XVI w. spalonych zostało tylko $4 \%$, a w XVII w. - $46 \%$ obwinionych.

Ta zbiorowa psychoza walki z czarownicami, którymi posługiwał się rzekomo szatan, owładnęła nawet wybitnych myślicieli owych czasów. Od przełomu wieków XVII i XVIII zaczęły pojawiać się jednak coraz częstsze głosy krytyki tych praktyk. Dzięki temu sejm polski zakazał kary śmierci za czary w 1776 r., czym wyprzedziliśmy nawet Francję oraz wiele i innych krajów zachodnioeuropejskch. Do dzisiaj wszakże jest to zjawisko nie w pełni zrozumiake dla historyków, socjologów i psychologów ${ }^{45}$.

3.7. Rozwój prawa karnego zmierzal do tego, by odpowiedzialność karna oparta była na dwóch podstawach: obiektywnej i subiektywnej. Przez długi czas ta odpowiedzialność opierała się tylko na podstawie obiektywnej

${ }^{45}$ K. B a ndurski, Ostatni proces o czary w Tarnowie (1756), Zesz. Wojn. 1995, 4, nr 10, s. 20-21; Das Ende der Hexenverfolgung, Hrsg. G. Meier, Stuttgart 1995; H. K a r b ow ni k, Sprawa prowadzenia procesów o czary w przedrozbiorowej Polsce $w$ świetle ówczesnego prawa karnego kanonicznego i polskiego, Kościół i Prawo 1998, nr 13, s. 165-174; W. Ko o c z, Procesy czarownic $w$ Zielonej Górze $w$ XVII w., Stud. Zielonog. 1997, nr 3, s. 47-54; $\mathrm{K}$. L a mbrecht, Hexenverfolgung und Zauberprozesse in den schlesischen Territorien, Köln-Weimar-Wien 1995; T. M a c i ej e w s k i, Narzędzia tortur squdów bożych i prób czarownic, Koszalin 1997, s. 131; M. Mik ołajczyk, O plawieniu czarownic $w$ Gdowie $w 1689$ r. Kartka $z$ dziejów miejskiego procesu karnego w Polsce, [w:] SDPiPP, t. 4, Łódź 1999, s. 121-129; P. O e r tm a n, Hexenprozesse am Reichskammergericht, Köln 1997, M. P i l a s z ek, Litewskie procesy czarownic $w$ XVI-XVIII $w$. , Odr. i Ref. 2002, nr 45, s. 7-35; tenże, Procesy czarownic $w X V I-X V I I I w$. Nowe aspekty, Odr. i Ref. 1998, $\mathrm{nr} 42$, s. 81-103; S. S almonowicz, Procesy o czary w Polsce. Próba rozważán modelowych, [w:] Prawo wczoraj [...] prof. K. Sójce-Zielińskiej, s. 303-322; t e n ż e, Vom Unfug der Hexenprozesse, APH 1996, 74, s. 173-180; K. Szkurłatowski, Gdańskie procesy czarownic w XV-XVII w. na tle ówczesnych przemian religijnych, [w:] Protestantyzm, Gdańsk 1997, s. 209-228; t e n ż e, Praktyki magiczne czarownic $w$ świetle ksiegi sqqdowej Zielonej Góry $z$ XVII w., SKH Sobótka 1995, $50, \mathrm{nr} 3-4$, s. 247-253; t e ṅ̇ e, Proces inkwizycyjny przeciwko czarownictwu w praktyce sadów soltysich województwa malborskiego na przelomie XVII i XVIII w., Rocz. Elbl. 1997, nr 15, s. 45-53; Vom Unfug des Hexen-Prozesses, wyd. H. Lehmann i O. Ulbricht, Wiesbaden 1992; T. Wi ślicz, Czary przed sqdami wiejskimi w Polsce w XVI-XVIII w., CPH 1997, nr 49, z. 1-2, s. 47-63; H.-J. W ol t, Geschichte der Hexenprozesse. Holocaust und Massepsychose vom 16-18 Jahrhundert, Erlensce 1995; zob. też S. Płaza, Historia prawa.., s. 382-383. 
- w postaci związku przyczynowego między zachowaniem się sprawcy a skutkiem przestępnym - oraz na bezprawności skutku. Była to więc odpowiedzialność skutkowa, obiektywna. Stopniowo wszakże narastaly tendencje do subiektywizacji odpowiedzialności, do różnicowania odpowiedzialności $w$ zależności od psychicznego stosunku sprawcy do czynu. W ten sposób powoli wykształcało się pojęcie winy: w Europie zachodniej od XII w., w Polsce od XIII w. Dzięki temu odpowiedzialność karna została oparta na obu podstawach: obiektywnej (skutku) i subiektywnej (winie). Najpierw wystapilo to $\mathrm{w}$ doktrynie $\mathrm{i}$ praktyce miast whoskich, a w Polsce - od statutów Kazimierza Wielkiego (pol. XIV w.). Obie te podstawy rozumiane były różnie. Związek przyczynowy aż do rozbiorów Polski rozumiany byl szeroko. Pojmowanie winy przeszło dlugą ewolucję zarówno w Europie, jak i w Polsce; stopniowo wykształciła się wina umyślna (statuty Kazimierza Wielkiego), wina nieumyślna i przypadek (pol. XVII w.). Nie udało się jednak opracować ani u nas, ani gdzie indziej ogólnego i pełnego pojęcia winy i jej stopni, chociaż ich mało precyzyjne, często kazuistyczne rozróżnianie miało wpływ na wymiar kary ${ }^{46}$.

3.8. Od schyłku średniowiecza aż do czasów Oświecenia dominującą racjonalizacją (uzasadnieniem) kary w europejskiej doktrynie i praktyce sądowej byla teoria odstraszania, według której głównym celem kary było odstraszanie potencjalnych przestępców od popełniania przestępstw. Ta teoria, występująca w większości krajów europejskich, była szczególnie rozbudowana w państwach o ustroju absolutnym. W Polsce nie miała tak szerokiego zastosowania. Tym niemniej przyniosła od końca XV w. nawet $w$ prawie ziemskim pewne zaostrzenie represji karnej. Natomiast idea odstraszania dominowała w prawie miejskim, chociaż nie w takim stopniu, jak w krajach prawa niemieckiego. Pociągnęło to za sobą rozpowszechnienie się kary śmierci i kar okaleczających, które wykonywane były publicznie. Naruszano wskutek tego niejednokrotnie zasadę proporcjonalności kary do przestępstwa; bywało, że w takim stopniu, iż można tu było dopatrzeć się elementu raczej zemsty, a nie tylko prewencji ${ }^{47}$.

${ }^{46} \mathrm{M}$. M i k ol a jez y k, Okoliczności wylaczajace wine w prawie karnym miast polskich XVI-XVIII w., Probl. Pr. Kar. 1997, nr 22, s. 88-113; te nże, Stadia popetnienia przestepstwa. Z badań nad miejskim prawem karnym w Polsce XVI-XVIII w., Pr. Nauk. US 1996, nr 1581, s. 41-54.

${ }^{47} \mathrm{D}$. Ka czor, Wladza i przestepcy. Sankcje karne za przestepstwo kryminalne $w$ Gdańsku XVI-XVIII w., [w:] Mieszczaństwo gdańskie, Gdańsk 1997, s. 161-186; T. M a c i e j e w sk i, Wymiar kar $w$ dawnym Gdańsku, [w:] Studia europejskie, t. 2, Toruń 1998, s. 287-300; M. M ik oła jc zyk, System kar w prawie miejskim w Polsce czasów Oświecenia (na przykladzie Krakowa w drugiej polowie XVIII w.), Pr. Nauk. US 1996, nr 1581, s. 103-137; M. S u r k o n t, Wykonywanie kar w Gdańsku, Gd. St. Pr. 1997, nr 1, s. 49-54; J. T a z bi r, Okrucieństwo w nowożytnej Europie, wyd. 2, Kraków 2000; P. W i ą zek, System kar w ordynacji ziemskiej księstwa opolsko-raciborskiego z roku 1562, [w:] Studia historycznoprawne, Wroclaw 1997, s. 47-63; t enż e, Racjonalizacja kary w postanowieniach ślqskich ordynacji ziemskich, [w:] Studia historycznoprawne, Wrocław 2001, s. 83-103;. 
3.9. Różnice społeczne przy wymierzaniu kary w Polsce utrzymały się dłużej niż gdzie indziej. Szczególnie jaskrawo występowało to w odniesieniu do szlachty, która była tu wyjątkowo uprzywilejowana (np. za zabójstwo chłopa karany był tylko grzywną, a chlop za zabójstwo szlachcica - zawsze karą śmierci). Również duchowni cieszyli się szczególnym uprzywilejowaniem $w$ prawie karnym. Przeciwko tym skrajnym nierównościom stanowym występowali już w XVI w, nasi czołowi myśliciele, w szczególności A. Frycz-Modrzewski, który domagał się ścigania z urzędu każdego zabójstwa oraz karania za nie zawsze śmiercią. Postulat równego prawa karnego wysuwali także humanitaryści (druga poł. XVIII w.). Pełną równość wobec prawa karnego przewidywały w 1792 r. ustawa o sądach sejmowych oraz projekt kodeksu Stanisława Augusta. Ponadto, zgodnie z żądaniami humanitarystów, obie te legislacje przewidywały zasade orzekania kar oznaczonych przez prawo $\mathrm{w}$ myśl formuły nulla poena sine lege. $\mathrm{W}$ tym czasie nie była to jeszcze zasada szeroko stosowana.

3.10. W ślad za podziałem przestępstw na prywatne i publiczne również kary dzielono na prywatne i publiczne. Kary prywatne obejmowały krwawą zemstę oraz kary pieniężne. Krwawa zemsta była sposobem dochodzenia sprawiedliwości w drodze samopomocy, zwłaszcza w razie zabójstwa. W okresie rozbicia feudalnego nasiliła się w całej Europie, przekształcając się we wróżdy feudalne - tj. prywatne wojny, nieraz o dużym zasięgu. W związku z tym zaczęto ją stopniowo ograniczać; w Polsce od drugiej połowy XIV w. - wycofywano się z ich stosowania, a od XVI w. obowiązywał bezwzględny zakaz wróżd. Najwcześniej i najszerzej ograniczały zemstę prywatną rozwinięte systemy prawne, jak prawo kanoniczne czy prawo włoskie. W szerszym zakresie i dłużej dopuszczało ją prawo niemieckie.

3.11. Kary pieniężne pojawiły się dosyć wcześnie. Były ekwiwalentem przede wszystkim odwetu, świadczono je w zamian za rezygnacje z krwawej zemsty, z prawa odwetu; dopuszczalne były także jako środek wykupienia się od kar na życiu i zdrowiu w ogóle. W ten sposób powstał system zastępczych kar pieniężnych zwany systemem kompozycyjnym. Rozpowszechniony byl w prawodawstwach wielu krajów, zwłaszcza wcześniejszych okresów feudalizmu. W prawie polskim uksztaltowal się zapewne jeszcze przed rozbiciem dzielnicowym; szeroko rozbudowany został w XII-XIII w., a odgrywał największą rolę w systemie kar za przestępstwa prywatne w wiekach XIV i XV; stosowany był także przy przestępstwach publicznych. Przetrwał w Polsce, chociaż w ograniczonym zakresie, najdłużej - aż do rozbiorów, co było związane $z$ utrzymywaniem się $u$ nas podziału przestępstw na publiczne i prywatne oraz uprzywilejowaniem szlachty. System kar pieniężnych jako alternatywnych stwarzał uprzywilejowaną sytuację dla bogatych, umożliwiając im wykupienie się od kary, podczas gdy ubodzy, których nie stać było na zapłacenie kary, przypłacali przestępstwo życiem lub kalectwem. Takie zasady 
obowiązywały w średniowieczu zarówno w Polsce, jak i w Europie. W miare pogłębiania się stosunków feudalnych i kształtowania się stanów kary pieniężne ulegały zróżnicowaniu w zależności od pozycji stanowej, a także w ogóle pozycji społecznej osoby zabitej lub pokrzywdzonej. Do najbardziej rozpowszechnionych kar pieniężnych prywatnych należały: główszczyzna i nawiązka. Główszczyzna była to suma pieniężna składana za "głowę" zabitego. Nawiązka była karą pieniężną za uszkodzenie ciała (okaleczenie, zranienie lub pobicie) ${ }^{48}$.

3.12. Kary publiczne grozily za przestępstwa publiczne. Ich znaczenie wzrastało w miare, jak malało zastosowanie kar kompozycyjnych (prywatnych). Najwcześniej proces ten zaznaczył się we Włoszech i Niemczech (XIII-XV w.), a od XVI w. w krajach europejskich w ogóle wykluczono możliwość stosowania kar kompozycyjnych, co związane było ze zwycięstwem zasady publicznoprawnej.

Kary publiczne obejmowały przede wszystkim karę śmierci i kary okaleczające. Mniejsze znaczenie miały pozostałe kary, jak proskrypcja, infamia, banicja, wygnanie, niewola, kary na czci, kary cielesne, kary pozbawienia wolności, kary majątkowe, kary utraty urzędu.

3.13. Od średniowiecza kara śmierci stosowana była dosyć często zarówno w Europie, jak i w Polsce. Od końca średniowiecza kara śmierci stała się głównym instrumentem realizacji teorii odstraszania. Tak było przede wszystkim w krajach o ustroju absolutnym. W Polsce podobny zakres i formy jej stosowania występowały tylko w sądownictwie miejskim. Natomiast prawo ziemskie uciekało się do tej kary jedynie $w$ przypadkach najcięższych przestępstw. Kara śmierci mogła być zwykła lub kwalifikowana. Zwykła występowala $\mathrm{w}$ średniowieczu przez ścięcie lub powieszenie, a w czasach nowożytnych doszło jeszcze utopienie lub rozstrzelanie. Kwalifikowana kara śmierci połączona była ze szczególnymi udręczeniami przez obcinanie kolejne członków, spalenie żywcem, łamanie kołem, wbicie na pal, zakopanie żywcem. W dobie Oświecenia, kiedy silne byly dążenia humanitarne w prawie karnym (ziemskim), pojawily się tendencje w doktrynie, sejmie i Radzie Nieustającej do całkowitego zniesienia kary śmierci, a przynajmniej znacznego jej ograniczenia przez szerokie stosowanie sejmowego prawa łaski i ścisłe określenie przestępstw zagrożonych tą karą, przy jednoczesnym zawężeniu ich kręgu. Kara śmierci miala zostać zastąpiona karą pozbawienia wolności, którą łączono by $\mathrm{z}$ użytecznymi dla spoleczeństwa robotami publicznymi. Zniesiono więc karę śmierci za czary w 1776 r. Projekt litewski kodeksu Stanisława Augusta w ogóle nie przewidywał kary śmierci. W Europie w tym czasie kara śmierci była nadal szeroko stosowana. W Anglii przewidziana była

\footnotetext{
${ }^{48}$ J. M at u szewski, Chlopska glówszczyzna cywilna w Polsce, [w:] ten że, Pisma, t. 2, Łódź 2000, s. 143-184; te nże, Glówszczyzna chlopska i szlachecka, [w:] te nże, Pisma, t. 2, s. 133-142; P. W i ą ze k, Kary majątkowe w postanowieniach ordynacji ziemskich, Acta Univ. Wrat. 2000, 2213, Prawo 270, s. 59-83.
} 
w ok. 190 wypadkach (nawet za drobną kradzież sklepową). W Austrii Theresiana (1768 r.) przewidywała liczne wypadki okrutnych form kwalifikowanej kary śmierci. Słynna Józefina (1787 r.) utrzymała tę karę, ale tylko w postępowaniu doraźnym. W Prusach Landrecht (1794 r.) utrzymywał jeszcze w ok. 60 przypadków kary śmierci (i to jako karę wyłączną), w tym wiele kwalifikowanych form ${ }^{49}$.

3.14. Kara pozbawienia wolności $w$ średniowieczu miała drugorzędne znaczenie; uwięzienie służyło przede wszystkim jako środek do przetrzymywania przestępców do czasu ich ukarania. Jeszcze w czasach nowożytnych, w krajach o ustroju absolutnym, rozwijała się wolno wobec szeroko stosowanej kary śmierci. Natomiast w Polsce ten rozwój był szybszy. Dla szlachty była to kara wieży, którą sejm zróżnicował (w 1538 r.) na wieżę dolną (o bardzo surowym reżimie) i górną (o łagodnych warunkach). Wprawdzie w obu pobyt był krótki, ale dotkliwość pierwszej mogła doprowadzić do utraty zdrowia, a nawet życia skazańca. Niezależnie od tych kar, wlaściwe więzienia państwowe pojawiły się w Polsce dopiero w XVII-XVIII w. w twierdzach dla długoletnich skazańców, których zakuwano w łańcuchy i zmuszano do ciężkich robót. Warunki bytu więźniów zarówno w Polsce, jak i w Europie były okropne. Doktryna humanitarna nie tylko opowiadała się za szerszym stosowaniem kary pozbawienia wolności w miejsce kary śmierci, ale także za takim jej wykonywaniem, by spełniała ona zadania resocjalizacyjne. Takie nowoczesne więzienie, jedno z pierwszych w Europie, powstało w Warszawie w wyniku reformy tzw. więzienia marszałkowskiego $(1767$ r.). Karę pozbawienia wolności jako środek poprawy przestępcy przewidywał także Kodeks Stanisława Augusta. Pojawily się również domy poprawy i domy pracy przymusowejo ${ }^{50}$.

${ }^{49}$ P. B a r tu 1 a, Kara śmierci - powracajacy dylemat, Kraków 1998, s. 158; B. B a r tu siak, Filozoficzne aspekty kary śmierci w myśli Platona $i$ św. Tomasza, Ann. UMCS 1999, Sec. 46, s.161-177; te n ż e, Problematyka kary śmierci $w$ nowożytnej szkole prawa naturalnego, Rzesz. Zesz. Nauk. Pr.-Ek. 2000, 29, s. 29-45; H. D o bi o s ch, Historyczne aspekty kary smierci w katolickiej teologii moralnej, St. Teol.-Hist, S1.-Op. 2000, nr 20, s. 229-238; P. J a gl a k, Przypadek wyproszenia od kary śmierci z 1791 r., CPH 2002, nr 54, z. 2, 197-200; P. J u r e k, Landfrydy ślaskie jako wyraz ksztaltowania siẹ kary publicznej, [w:] W kręu dziejów, Warszawa 1999, s. 18-23; W. Organiściak, Kara śmierci w prawie wojskowym Rzeczypospolitej szlacheckiej od XVI do XVIII w., Pr. Nauk. US 1994, 1445, Prace Pr. Kar. 20, s. 79-93; M. J. P tak, Wypraszanie od kary śmierci na Slasku - casus z 1563 r., [w:] Studia z historii [...] prof. J. Walachowiczowi, s. 323-328; J. S obcza k, Szubienica slupecka, Rocz. Koniń. 1997 , nr 11, s. 175-178; T. Sli pk o, Kara śmierci z teologicznego i filozoficznego punktu widzenia, Kraków 2000; J. T r z ci ń s k i, Miecz katowski, pregierz, szubienica. Zabytki jurysdykcji karnej na Dolnym Ślasku (XIII-XVIII w.), Wroclaw 2001.

${ }^{50} \mathrm{~W}$. Feliński, Wokól problematyki domów poprawy na terenie Pomorza Zachodniego $i$ Srodkowego $w$ XVIII-XIX w., Mat. Zach.-Pom. 1999, nr 45, s. 615-628; D. K a c zor, Dom poprawy (Zuchthaus) $w$ Gdańsku $w$ XVII-XVIII w., Rocz. Gd. 1996, nr 56, z. 1, s. 43-63; M. M i k oł a j czy k, Krakowski dom poprawy. $Z$ badań nad dziejami więziennictwa w osiemnastowiecznej Polsce, CPH 1998, nr 50, z. 1, s. 57-82; F. Nowi ń ski, Syberyjskie 
3.15. Kary cielesne stosowane były $w$ różnych systemach prawnych. Występowały one w państwach germańskich i słowiańskich, w późniejszych państwach zachodnioeuropejskich, średniowiecznych i epoki absolutyzmu, w prawie miejskim i wiejskim, a nawet prawie kanonicznym. Kar cielesnych nie przewidywał już Kodeks Stanisława Augusta. Do kar cielesnych należała przede wszystkim kara chłosty, którą często stosowano w sądownictwie miejskim i wiejskim, gdzie była najpopularniejszą sankcją ${ }^{51}$.

3.16. Kara konfiskaty majątku, orzekana (razem $z$ innymi karami) za ciężkie przestępstwa, była również krytykowana przez humanitarystów, bo sprzeczna jest $\mathrm{z}$ zasadą indywidualizacji odpowiedzialności karnej. W Polsce w drugiej połowie XVIII w. orzekana była już rzadko. Nie przewidywał jej Kodeks Stanislawa Augusta i z tego samego czasu rewolucyjny kodeks karny francuski (z 1791 r.). Natomiast dopuszczal ją nieco późniejszy Landrecht pruski $\left(1794\right.$ r.) oraz prawo karne innych krajów ${ }^{52}$.

4.1. Wobec braku rozróżnienia bezprawia karnego od cywilnego przez długi czas nie było różnic między procesem w sprawach karnych i cywilnych. $\mathrm{Z}$ czasem jednak wykształcily się odrębności proceduralne w sprawach karnych i cywilnych. Najwcześniej wystąpiły one w procesie angielskim (koniec XII w.). $\mathrm{Na}$ kontynencie pojawil się podział skarg na karne i cywilne oraz mieszane (XIII w.). Dało to podstawę do kształtowania się odrębności proceduralnych, ale pełne ukształtowanie się procesu karnego i cywilnego nastąpiło w Europie zachodniej dopiero od XVI w. Proces karny odtąd oparty został na inkwizycyjności, a cywilny - na skargowości ${ }^{53}$.

zeslania w epoce Katarzyny II, [w:] Rosja-Polska, Szczecin 1998, s. 73-99; A. Od r z y w o ls k a Kidawa, Karcer $w$ dawnym klasztorze bernardyńskim w Swiętej Annie, Ziemia Częstoch. 1996, nr 23, s. 79-97; K. P a wla k, Za kratami wiezzień i drutami obozów. Zarys dziejów więziennictwa w Polsce, Kalisz 1997; K. S ó j k a-Zi e li ńs k a, Poglqdy humanitarystów epoki Oświecenia na kare wygnania, [w:] Studia $z$ historii państwa i prawa, $i$ idei. Prace dedykowane prof. J. Malarczykowi, Lublin 1997, s. 353-366; zob. też S. P ła za, Historia prawa..., s. 418.

${ }^{51}$ M. Mikola jczyk, Kary cielesne $w$ prawie miejskim w Polsce XVI-XVIII w., Miscel. Biał. 1995, s. 71-85; S. M ilew ski, Kara wystawienia na widok publiczny, Prz. Więź. Pol. 1993, $\mathrm{nr}$ 4-5, s. 30-49; W. Orga niścia k, $Z$ badań nad karami na ciele $w$ prawie wojskowym Rzeczypospolitej szlacheckiej w XVI-XVIII w., [w:] $Z$ dziejów prawa, cz. 3, Katowice 2002, s. $25-41$.

${ }^{52} \mathrm{~K}$. Goźdź-R oszkowski, O obowiqzku rozdawania skonfiskowanych dóbr ziemskich $w$ ustawodawstwie polskim XVII-XVIII w., [w:] SDPiPP, t. 5, Łódż 2000, s. 151-158; J. M a tuszewski, Problem konfiskaty dóbr szlacheckich $w$ dawnej Polsce, [w:] t e nże, Pisma, t. 2, Łódż 2000, s. 5-10; I. R zeplińsk a, Konfiskata mienia. Studium z historii polityki kryminalnej, Warszawa 1997.

${ }^{53}$ S. Pła z a, Historia prawa..., s. 419-424, 426. 
Odmiennie natomiast rozwijał się proces w Polsce. Przede wszystkim normalna procedura sądowa wykształcila się tutaj dopiero w XIII w. Nie przewidywala ona różnic $w$ sprawach karnych i cywilnych. Taką jednolitość procesu sądowego utrzymały Statuty Kazimierza Wielkiego oraz w zasadzie późniejsze regulacje prawne, a także ich projekty. Z czasem jednak powstały pewne odrębności w sprawach karnych, z których zacznie rozwijać się model procesu mieszanego. W miastach ukształtował się (pod wpływem Karoliny) proces inkwizycyjny ${ }^{54}$.

4.2. Podstawą nowożytnego procesu cywilnego w Europie był proces rzymsko-kanoniczny, oparty na rzymskich zasadach procesowych rozwijanych przez doktrynę i sądy kościelne. Najpierw stosowano go w sądach komun włoskich (XIII w.), a stąd przenikal do innych krajów europejskich. Oparty był na zasadach skargowości (rozpoczynała go skarga powoda), pisemności, dyspozycyjności (strony dysponowały przedmiotem sporu), kontradyktoryjności (walki procesowej stron), legalnej teorii dowodów (prawo $\mathrm{z}$ góry określało wartość poszczególnego dowodu), prawdy formalnej oraz możliwości stosowania analogii. Cechował go znaczny formalizm, co powodowało przewlekłość procesu $^{55}$.

Polski proces cywilny (zarazem w sprawach karnych) mial w zasadzie charakter rodzimy. Wpływy na niego procesu rzymsko-kanonicznego zaznaczyły się dopiero w dużym stopniu przy jego kodyfikacji (1523 r.). Przez caly czas byl to proces: skargowy, kontradyktoryjny, ustny $\mathrm{i}$ jawny. W średniowieczu był mniej formalistyczny niż procesy zachodnioeuropejskie. Zresztą ten formalizm $w$ poważnym stopniu zaczęła ograniczać zasada dyspozycyjności (w pełni uksztaltowana w XV w.), która pozwalała stronom zmieniać szereg ogólnie obowiązujących reguł procesowych. Przy kodyfikacji (1523 r.) nastąpiło

${ }^{54}$ M. Delimat a, Proces karny w miastach polskich XVI w. Uwagi w świetle prac Bartlomieja Groickiego, CPH 2003, nr 55, z. 1, s. 189-200; A. Gulczyński, O torturach i karach $w$ dawnym Poznaniu, Poznań 2001; M. M ikołajczyk, Chlosta jako sposób wymuszania zeznań $w$ procesie karnym miast polskich XVI-XVIII w., [w:] SDPiPP, t. 7, Lódź 2002, s. 211-222; te nże, Dowód z zeznań świadków w miejskim procesie karnym w Polsce XVI-XVIII w., Probl. Pr. Karn. 2001, nr 24, s. 187-201; tenże, $O$ przysiędze dowodowej $w$ miejskim procesie kryminalnym $w$ Polsce XVI-XVIII $w .$, [w:] $Z$ dziejów prawa, cz. 3, Katowice 2002, s. 42-67; t e n ż e, Prawo oskarżonego do obrony w praktyce sqqdów miejskich w Polsce XVI-XVIII w., [w:] Ustrój $i$ prawo [...] Studia dedykowane prof. S. Grodziskiemu, Kraków 2000, s. 397-411; t e nże, Proces kryminalny w Bochni w 2 pol. XVII w., [w:] Studia $z$ historii [...] prof. J. Walachowiczowi, s. 243-259; t e nż e, Proces kryminalny w Oświęcimiu w 1 pol. XVIII w., [w:] Dyplomacja [...] Ksiega [...] ofiarowana prof. H. Kocójowi, Katowice 2001, s. 234-242; t e nż e, $Z$ dziejów wymuszania zeznań w Polsce (na podstawie praktyki krakowskiego sqdu miejskiego w 2 pol. XVIII w.), Pr. Nauk UŚ 1995, 1485, Pr. Praw Kar. 21, s. 86-96.

${ }^{55}$ W. Lit e w sk i, Der römisch-kanonische Zivilprozess nach den älteren ordines iudiciarii, t. 1-2, Kraków 1999; zob. też S. Płaza, Historia prawa..., s. 430-431. 
dalsze ograniczenie formalizmu i uproszczenie postępowania, zwłaszcza egzekucyjnego ${ }^{56}$.

4.3. Proces $w$ sprawach karnych we wczesnym średniowieczu był oparty na tych samych zasadach, jakie stosowano w sprawach cywilnych, co wiązało się z brakiem rozróżnienia bezprawia karnego od cywilnego. Zaczęto rozróżniać skargi karne od cywilnych (XIII w.). Przez jakiś czas proces $w$ sprawach karnych nadal toczył się według dotychczasowych zasad. Stopniowo jednak karny proces skargowo-kontradyktoryjny był wypierany przez postępowanie inkwizycyjne, którego początki sięgają XIII w. Do wieku XVI rozpowszechniło się ono w większości krajów europejskich; odpowiadało zwłaszcza władcom absolutnym. Wszczynane było $\mathrm{z}$ urzędu; ten sam organ prowadził śledztwo, oskarżal i wyrokował oraz wykonywał wyrok. Postępowanie było tajne i pisemne; koronnym dowodem bylo przyznanie się do winy, co osiągano najczęściej, używając tortur; oskarżony nie miał prawa ani do obrony, ani do apelacji. Był to zatem bardzo niehumanitarny proces, pozwalal na arbitralność i nadużycia władzy absolutnej, ale zarazem był dla niej użyteczny, bo umożliwiał skuteczne podporządkowywanie sobie poddanych ${ }^{57}$.

4.4. Szlachta polska była przeciwna postępowaniu inkwizycyjnemu, bo naruszałoby jej przywileje i mogło być wykorzystywane przez króla dla wzmocnienia swej władzy. Dlatego doprowadziła do likwidacji (XV w.) urzędu justycjariusza, którego działanie miało charakter inkwizycyjny. W czasach nowożytnych trzymała się procesu skargowego (wszczynanego skargą pokrzywdzonego) także w sprawach karnych, uważając go za jedną z gwarancji „zlotej wolności" ${ }^{58}$.

4.5. W miarę wszakże jak wzrastało w Polsce znaczenie zasady publicznoprawnej i rozszerzal się krąg przestępstw publicznych w ziemskim procesie skargowo-kontradyktoryjnym dopuszczano do głosu w stadium postępowania przygotowawczego elementy inkwizycyjne, w celu zwiększenia skuteczności ścigania przestępców. Coraz większego znaczenia nabierała (od XVI w.) instytucja skrutynium (śledztwa) przeprowadzanego z urzędu przez specjalnego funkcjonariusza sądowego, instygatora (oskarżyciela publicznego), który

${ }_{56}$ M. Sliwk a, D. M iścicka-Sliwka, Srodki dowodowe w dawnej Polsce, cz. 1: Ordalia, przyznanie sie do winy, przysiega, wizja lokalna, dowód z dokumentu, dowód ze świadków, Arch. Med. Sąd. i Krimonol. 1999, nr 49, z. 4, s. 203-209.

${ }^{57}$ K. F a r ringt on, Historia kar i tortur, wyd. 2, Warszawa 1999; J. K or edczu k, Kilka uwag o udziale organów administracji $w$ inkwizycyjnym procesie karnym $i$ ich wplywie na jego przebieg, Acta Uniw. Wrat. 1994, 1692, Prawo 240, s. 169-183; T. M a ciejewski, Sredniowieczne narzędzia tortur. Uwagi o wloskiej wystawie archeologicznej, CPH 1997, nr 49, z. 1-2, s. 241-246; W. U r u s z za k, Model procesu karnego wedlug Practica [...] Carptzowa, [w:] Zasady procesu karnego [...] Ksiega ku czci prof. S. Waltosia, Warszawa 2000, s. 154-165.

${ }_{58}$ M. B or u cki, Temida staropolska, wyd. 2, Warszawa 2001, s. 307. M. M i k oła j cz y k, $Z$ badań nad problemem stosowania tortur w prawie ziemskim w Polsce, Biał. St. Pr. 1994, nr 2, s. $45-54$. 
występowal także $\mathrm{z}$ oskarżeniem $\mathrm{w}$ sądzie. W tym stadium postępowania przed sądem stosowano nadal elementy skargowo-kontradyktoryjne. Taki zaś model procesu określa się mianem procesu mieszanego ${ }^{59}$.

Ustawowe pełniejsze unormowania tego modelu pojawily się $\mathrm{w}$ drugiej połowie XVIII w. W szczególności Zbiór praw z 1778 r. szeroko zakreślal krąg przestępstw publicznych i wszystkie miały być ścigane $\mathrm{z}$ urzędu przez instygatorów różnych szczebli. Kodeks Stanisława Augusta nakazywał we wszystkich przestępstwach, nawet najdrobniejszych, dotąd ściśle prywatnych, przeprowadzać postępowanie przygotowawcze $\mathrm{z}$ urzędu; postępowanie dowodowe miał przeprowadzać tylko sąd wyrokujący; obowiazywać miała zasada jawności. Ustawa o sądach sejmowych o szerokim zakresie problematyki sądowej (1792 r.) przewidywała mocną pozycję dla instygatorów, zapewniała oskarżonemu szereg gwarancji procesowych, jak prawo do obrony, domniemanie niewinności, tłumaczenie wątpliwości na korzyść oskarżonego; sąd miał dążyć do ustalenia prawdy materialnej (obiektywnej). Ustawa o sądach sejmowych przewidywała mieszany typ procesu przed tymi sądami. W sądach powstania kościuszkowskiego był on w pełni stosowany, co było wyjątkiem w skali ówczesnej Europy i stanowiło wielką nowośćco.

4.6. Ten nowoczesny (mieszany) proces karny postulowała doktryna humanitarna prawa karnego (XVIII w.), która ostro zwalczała proces inkwizycyjny. Kształtowanie się wszakże modelu mieszanego procesu karnego możliwe było dopiero po obaleniu ustroju absolutnego. We Francji nastąpiło to w wyniku wielkiej rewolucji francuskiej, a w innych krajach europejskich - dopiero po Wiośnie Ludów (1848 r.), w okresie powstawania ustrojów liberalno-demokratycznych ${ }^{61}$.

4.7. W Polsce demokracja szlachecka ewoluowala od początku XVI stulecia w kierunku monarchii konstytucyjnej. Jej zasadnicze zręby (podstawowe zasady ustroju państwowego i szlacheckie prawa obywatelskie) określiły (wraz $\mathrm{z}$ innymi regulacjami prawnymi i przywilejami szalcheckimi) artykuły henrykowskie (1573 r.). Odtąd monarcha musiał rządzić państwem zgodnie $\mathrm{z}$ prawem ustrojowym, co stanowi istotę monarchii konstytucyjnej. Król odpowiadał konstytucyjnie za swe rządy przed szlachtą za łamanie prawa, aż do utraty tronu, na podstawie prawa oporu $\mathrm{z}$ artykułów henrykowskich.

${ }^{59}$ M. Pilaszek, W poszukiwaniu prawdy. O dzialalności sqdów kryminalnych $w$ Koronie XVI-XVIII w., PH 1998, R. 89, nr 3, s. 361-368.

${ }^{60}$ A. Lity ński, O sqqdach kryminalnych insurekcji 1794 r., Wiek. Ośw. 1995, nr 11, s. 103, 128; t e nże, Wymiar sprawiedliwości $w$ insurekcji $1794 \mathrm{r}$. Glówne problemy prawa $i$ sqdów powszechnych, [w:] Powstanie..., Kraków 1996, s. 23-30; t e nż e, Wymiar sprawiedliwości (1794), [w:] Powstanie, Warszawa 1998, s. 50-71; zob. też S. Pła za, Historia prawa..., s. $590-592$.

${ }^{61} \mathrm{~S}$. Płaza, Historia prawa w Polsce na tle porównawczym, cz. II: Polska pod zaborami, Kraków 1998, s. 173-174. 
Reformy Sejmu Wielkiego przekształciły Polskę (1791 r.) w nowożytną monarchię konstytucyjną o ustroju liberalno-demokratycznym (dla szlachty, stanu poszerzonego o aktywne elementy mieszczańskie oraz inteligenckie i wojskowe). Taki zaś ustrój (dawniejszy i nowy) wykluczał z natury rzeczy, by w ślad za wzrostem znaczenia zasady publicznoprawnej ewolucja procesu ziemskiego poszła w kierunku procesu inkwizycyjnego; mógł to być tylko nowoczesny proces mieszany, w dużej zresztą mierze uksztattowany $z$ rodzimych pierwiastków ${ }^{62}$.

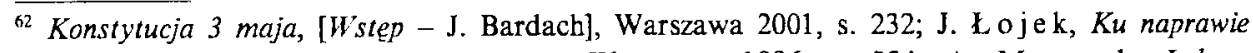
Rzeczypospolitej. Konstytucja 3 maja, Warszawa 1996, s. 234; A. M ąc za k, Jedyna $i$ nieporównywalna? Kivestia odręnności Rzeczypospolitej w Europie XVI-XVII w., KH 1993, 106, nr 4, s. 121-136; W. W i tk ow s k i, Pierwsze konstytucje nowożytne, Lublin 1996, s. 95. 